\title{
Effect of caffeine on lipid profile in ciclism practitioners
}

\author{
Antonio Felipe Correa Marangon*, Tatiana Helou, Deilys Vazquez Gonzalez \\ From International Society of Sports Nutrition: 9th Annual ISSN Conference and Expo \\ Clearwater, FL, USA. 22-23 June 2012
}

\section{Background}

Caffeine is a $\beta 2$ agonist that increases energy expenditure both at rest and during sports, increasing lipolysis and fatty acid oxidation. Caffeine may also increase the utilization of lipids as energy source during aerobic exercises.

\section{Methods}

The objective of this study was to investigate if caffeine can influence lipid profile in trained cyclists. 19 trained and familiarized male cyclists with a mean age of $35 \pm 8.1$ were randomly assigned to placebo $(n=7)$ and caffeine groups $(n=12)$. 30 minutes before the exercise each member of the caffeine group received $5 \mathrm{mg} / \mathrm{Kg}$ of caffeine. All participants underwent the same pre-test meal 2 hours before the test and were in 8 hours of fasting. Trials consisted of 60 min cycling at approximately $70-85 \% \mathrm{VO}_{2 \max }$. The study was double blind and a students $t$ test was used for our statistical analysis ( $p$ values $<0.05)$. Blood samples were collected before and after the test for total cholesterol, LDL-cholesterol, HDL-cholesterol and triglycerides.

\section{Results}

The average total cholesterol, before and after the caffeine group (CG), was $192.83 \pm 38 \mathrm{mg} / \mathrm{dL}$ and $212.75 \pm$ $48 \mathrm{mg} / \mathrm{dL}$, respectively. In the placebo group (PG) the mean total cholesterol was $162.71 \pm 92 \mathrm{mg} / \mathrm{dL}$ before and $180.43 \pm 43 \mathrm{mg} / \mathrm{dL}$ after. The HDL-cholesterol fraction in the caffeine group before and after was $43.42 \pm$ $12 \mathrm{mg} / \mathrm{dL}$ and $53 \pm 14 \mathrm{mg} / \mathrm{dL}$, respectively. In the placebo group the fraction HDL-cholesterol before was 34.57 \pm $8 \mathrm{mg} / \mathrm{dL}$ and after $42.43 \pm 11 \mathrm{mg} / \mathrm{dL}$. The LDL-cholesterol before and after in the caffeine group was $133.17 \pm$ $72 \mathrm{mg} / \mathrm{dL}$ and $143.5 \pm 99 \mathrm{mg} / \mathrm{dL}$, respectively. In the placebo group LDL-cholesterol before was $108.86 \pm 25 \mathrm{mg} / \mathrm{dL}$ and after $120.14 \pm 60 \mathrm{mg} / \mathrm{dL}$. Finally, the triglycerides in the caffeine group before and after were $81.83 \pm 24 \mathrm{mg} / \mathrm{dL}$ and $81.25 \pm 29 \mathrm{mg} / \mathrm{dL}$, respectively. In the placebo group the triglycerides before were $96.86 \pm 32 \mathrm{mg} / \mathrm{dL}$ and after $87.57 \pm 28 \mathrm{mg} / \mathrm{dL}$. There was a significant difference only in the values of total cholesterol $(\mathrm{p}=0.041)$ and HDL-cholesterol $(\mathrm{p}=0.001)$ between the participants of the caffeine group. Between the groups there was no significant difference $(\mathrm{p}>0.05)$ in all lipid markers (total cholesterol $\mathrm{p}=0.755$, triglycerides $\mathrm{p}=0.560$, HDL-cholesterol $\mathrm{p}=0.951$, LDL-cholesterol $\mathrm{p}=0.836$ ).

\section{Conclusions}

From the results that were found, we can conclude that caffeine doesn't interfere in the lipid profile in cyclists. In addition one exercise session was capable of increasing the plasmatic levels of HDL-cholesterol. We suggest that other studies should be conducted in order to check for how long the plasmatic levels of HDL-cholesterol remain elevated after cycling exercise.

Published: 19 November 2012

doi:10.1186/1550-2783-9-S1-P20

Cite this article as: Marangon et al:: Effect of caffeine on lipid profile in ciclism practitioners. Journal of the International Society of Sports Nutrition 2012 9(Suppl 1):P20.

* Correspondence: felipemarangon@terra.com.br

Centro Universitario UniCEUB, Brazil

(c) 2012 Marangon et al; licensee BioMed Central Ltd. This is an Open Access article distributed under the terms of the Creative 